\title{
Effect of quercetin on the transport of ritonavir to the central nervous system in vitro and in vivo
}

\author{
GONGWEN LIANG ${ }^{1}$ \\ NA LI ${ }^{2}$ \\ LIPING MA ${ }^{2}$ \\ ZHONGLIAN QIAN $^{3}$ \\ YUWEN SUN ${ }^{3}$ \\ LUWEN SHI ${ }^{1 *}$ \\ $\mathrm{LIBO} \mathrm{ZHAO}^{4 *}$ \\ ${ }^{1}$ School of Pharmaceutical Sciences \\ Peking University, Beijing 100191 \\ China \\ ${ }^{2}$ Institute of Clinical Molecular Biology \\ Peking University People's Hospital \\ Beijing 100044, China \\ ${ }^{3}$ School of Pharmacy \\ Guiyang Medical University \\ Guiyang 550004, China \\ ${ }^{4}$ Department of Pharmacy, Peking \\ University People's Hospital, Beijing \\ 100044, China
}

Accepted September 28, 2015

Online published January 15, 2016

\begin{abstract}
The aim of this study was to identify an effective flavonoid that could improve the intracellular accumulation of ritonavir in human brain-microvascular endothelial cells (HBMECs). An in vivo experiment on Sprague-Dawley rats was then designed to further determine the flavonoid's impact on the pharmacokinetics and tissue distribution of ritonavir. In the accumulation assay, the intracellular level of ritonavir was increased in the presence of $25 \mathrm{mmol} \mathrm{L}^{-1}$ of flavonoids in HBMECs. Quercetin showed the strongest effect by improving the intracellular accumulation of ritonavir by $76.9 \%$. In the pharmacokinetic study, the presence of quercetin in the co-administration group and in the pretreatment group significantly decreased the area under the plasma concentration-time curve $\left(A U C_{0-t}\right)$ of ritonavir by $42.2 \%(p<0.05)$ and $53.5 \%(p<0.01)$, and decreased the peak plasma concentration $\left(c_{\max }\right)$ of ritonavir by $23.1 \%(p<0.05)$ and $45.8 \%(p<0.01)$, respectively, compared to the control group (ritonavir alone). In the tissue distribution study, the ritonavir concentration in the brain was significantly increased 2-fold $(p<0.01)$, during the absorption phase $(1 \mathrm{~h})$ and was still significantly higher $(p<0.05)$ during the distribution phase $(6 \mathrm{~h})$ in the presence of quercetin.
\end{abstract}

Keywords: quercetin, flavonoids, ritonavir, blood-brain barrier, pharmacokinetics

Although highly active antiretroviral therapy (HAART) has greatly promoted the clinical treatment of HIV-1 infection, unresolved issues still remain. For instance, despite the fact that the blood viral load can be successfully reduced by HAART, the brain has proven to be a sanctuary site where the virus can reside relatively un-interrupted by therapeutic intervention (1-4). Thus, despite undetectable plasma viral RNA levels, low-level active replication of the virus is still present in the central nervous system (CNS), which can result in AIDS-related neurological complications (5). One of the strategies through which HIV-1 can reduce HAART efficacy in the brain is to rely on the presence of drug-

\footnotetext{
*Correspondence; e-mail: shilu@bjmu.edu.cn; libozhao2011@163.com
} 
efflux transporters in the blood-brain barrier (BBB), which include members of the ATP-binding cassette superfamily of proteins, such as P-glycoprotein (P-gp), multidrug resistance-associated protein (MRP), and breast cancer resistance protein (BCRP) (6). The HIV-1 protease inhibitors (HPIs) are key components of the HAART currently used to treat HIV-1 infection. A strong body of evidence suggests that HPIs are substrates of P-gp and, as a result, the limited ability of these drugs to transverse the BBB is attributed to the activity of this efflux transporter (7-11). A recent study showed that MDR1 specific drug-efflux function increases in BBB following co-exposure to HIV-1 and HPIs, which can reduce the penetration of HPIs into the infected brain reservoirs of HIV-1 (12).

To overcome tumor cell resistence caused by the over-expression of P-gp, a chemosensitizer is used to inhibit the efflux pump activity $(13,14)$. In principle, a similar strategy could be employed for HPIs therapy in order to enhance their distribution into sites such as the brain. Compounds such as verapamil, quinidine, and cyclosporin A have shown inhibitory effects on P-gp function. However, these compounds have an intrinsic toxicity due to their pharmacological activity and cannot be used safely at dosages required for the inhibition of drug efflux in vivo. Although some competitive inhibitors of P-gp are being tested as an approach to increase HPIs levels within the brain, their generalized inhibition has not been a safe or feasible approach since other organs also suffer from toxic xenobiotics (15). The search for chemosensitizers, which have the advantage of being effective inhibitors without side-effects, has focused on plant-derived flavonoids (16). Flavonoids are constituents of fruits, vegetables, herbal dietary supplements, as well as components of traditional Chinese medicines, and several flavonoids have been proven to modulate the function and expression of P-gp (17-19).

This study was designed to seek a safe and effective flavonoid to be used as an agent to increase HPIs levels within the brain, and to determine whether the result of flavonoids in vitro screening can be translated to in vivo effects on the distribution of HPIs into the brain.

\section{EXPERIMENTAL}

\section{Chemicals}

Ritonavir was purchased from Xiamen Henry Biochem Co., Ltd. (China). Saquinavir (an internal standard for high performance liquid chromatography-tandem mass chromatography, HPLC-MS/MS, analysis of ritonavir) with a purity $>99 \%$ was from United States Pharmacopoeia USA). Epicatechin gallate (ECG), hesperetin, kaempferol, quercetin, isoquercetrin, morinhydrate, chrysin and epicatechin (EC) (purity $\geq 99 \%$ ) were purchased from Nantong Feiyu Biological Technology Co., Ltd. (China). Verapamil was obtained from the China National Institute for Food and Drug Control (China). HPLC-grade methanol, acetonitrile, methyl tert-butyl ether, sodium tetraborate, ammonium formate and formic acid were purchased from Fisher Scientific Co. (USA). Bicinchoninic acid (BCA) protein assay kit and bovine serum albumin (BSA) were purchased from Tiangen Biotech (China). Distilled water was purified by a Derect- $Q{ }^{\circledR}$ Ultrapure Water System (Millipore, USA). The mobile phase used in HPLC-MS/MS was filtered using a $0.45-\mu \mathrm{m}$ membrane filter, and was supplied by Ameritech Co. (USA). 


\section{Animals}

Sprague-Dawley rats (6-10 weeks old, half male and half female, 250-300 g) were purchased from the Academy of Military Medical Sciences (Beijing, China) and raised in the animal room of the Peking University People's Hospital (Beijing, China), under a 12-h light-dark cycle. The animals were housed with free access to laboratory food and water ad libitum. Experimental procedures were reviewed and approved by the Ethics Committee of the Peking University People's Hospital, and were designed in accordance with the "Guide for the Care and Use of Laboratory Animals".

\section{Cell culturing}

Human brain-microvascular endothelial cells (HBMECs) were obtained from the Cell Bank of Type Culture Collection of the Chinese Academy of Sciences (Shanghai, China). HBMECs were incubated at $37{ }^{\circ} \mathrm{C}$ and in the presence of $5 \% \mathrm{CO}_{2}$ in Roswell Park Memorial Institute (RPMI) 1640 medium supplemented by $10 \%$ heat-inactivated fetal bovine serum, antibiotics (penicillin $100 \mathrm{U} \mathrm{mL}^{-1}$, streptomycin $100 \mathrm{\mu g} \mathrm{mL}^{-1}$ ), and $2 \mathrm{mmol} \mathrm{L}^{-1} \mathrm{~L}$-glutamine (all from Gibco/BRL, Germany). HBMECs whose monlayers reached confluence were selected and the old media were discarded. The cells were washed twice with phosphate-buffered saline (PBS) at $37^{\circ} \mathrm{C}$. A $0.25 \%$ trypsin-EDTA solution was then added to the cells at about 0.12 $\mathrm{mL} \mathrm{cm}{ }^{-2}$. After incubation at $37^{\circ} \mathrm{C}$ for $15 \mathrm{~min}$, the solution was discarded and new culture medium was added. The cells attached to the wall were gently fluctuated with the medium using a transfer pipette until the cells were detached and suspended. The cell density was adjusted to approximately $5 \times 10^{4} \mathrm{~mL}^{-1}$, and the cells were inoculated in a new culture flask. The medium was replaced every other day for regular cellular metabolism and the cells were subcultured approximately every three days in order to maintain proper cell density.

\section{Intracellular accumulation of ritonavir}

Accumulation of ritonavir in HBMECs was examined in confluent cell cultures as previously described $(20,21)$. HBMECs were seeded into a 6 -well plate, at $2 \times 10^{4}$ cells per well. When cells were $70-80 \%$ confluent, after the addition of $50 \mu \mathrm{mol} \mathrm{L}^{-1}$ of ritonavir, either $25 \mu \mathrm{mol} \mathrm{L}^{-1}$ of various flavonoids or $100 \mu \mathrm{mol} \mathrm{L}^{-1}$ verapamil (the drugs were dissolved in solvent with less than $1 \%$ of the RPMI 1640 by volume was added, except for the blank control. Cells were then incubated for another 4 hours in a $\mathrm{CO}_{2}$ incubator to reach a steady-state level. The cells were then rinsed ten times with the ice-cold PBS in a culture dish to remove the drugs on the cell surface. After the addition of $500 \mu \mathrm{L}$ of de-ionized water, the cells were transferred into a micro centrifuge tube with a cell scraper. The culture dish and cell scraper were rinsed with $500 \mu \mathrm{L}$ of de-ionized water and the suspension was then transferred into micro centrifuge tube. The cell suspension was processed with an ultrasonic cell disruption system 40 times (working frequency 10, disruption $3 \mathrm{~s}$, interval $3 \mathrm{~s}$ ). The lysate solution was centrifuged for $5 \mathrm{~min}$ at $13400 \mathrm{rpm}$, and the supernatant was kept at $-20^{\circ} \mathrm{C}$ until HPLC-MS/MS analysis.

\section{Pharmacokinetic study}

For the pharmacokinetic study, eighteen Sprague-Dawley rats were randomly divided into three groups ( $n=6$, half male and half female). The rats in the control group were 
orally administered ritonavir at a dose of $20 \mathrm{mg} \mathrm{kg}^{-1} \mathrm{bm}$ after being orally administered a blank solvent for 7 consecutive days. The rats of co-administration group were orally coadministered ritonavir at a dose of $20 \mathrm{mg} \mathrm{kg}^{-1}$ and quercetin at a dose of $100 \mathrm{mg} \mathrm{kg}^{-1} \mathrm{bm}$, after being orally administered a blank solvent for 7 consecutive days. The rats of pretreatment group were orally administered ritonavir at a dose of $20 \mathrm{mg} \mathrm{kg}^{-1}$ with quercetin at a dose of $100 \mathrm{mg} \mathrm{kg}^{-1}$, after being orally pretreated with $100 \mathrm{mg} \mathrm{kg}^{-1}$ quercetin for 7 consecutive days. The rats were fasted for 12 hours prior to the beginning of experiments (on the eighth day) and had free access to sterilized water.

After oral administration blood samples $(200 \mu \mathrm{L})$ were collected into heparinized centrifuge tubes at predetermined time intervals of $0.25,0.5,1,1.5,2,4,6,8,12,24$ and 48 hours from the retro orbital vein using heparinized capillary tubes. Control blood samples were obtained before dosing. Blood samples were immediately centrifuged for $5 \mathrm{~min}$ at 12,000 $\mathrm{rpm}$, and a $100-\mu \mathrm{L}$ aliquot of plasma was stored in a freezer at $-20^{\circ} \mathrm{C}$ until HPLC-MS/MS analysis.

\section{Tissue distribution study}

For the tissue distribution study, 36 Sprague-Dawley rats were randomly divided into 2 groups ( $n=18$, half male and half female). The rats were fasted for $12 \mathrm{~h}$ prior to the beginning of experiments and had free access to sterilized water. The rats were orally given a dose of $20 \mathrm{mg} \mathrm{kg}^{-1}$ of ritonavir with or without quercetin $\left(100 \mathrm{mg} \mathrm{kg}^{-1}\right)$. For the control, a blank solvent was given in comparable amounts $\left(5 \mathrm{~mL} \mathrm{~kg}^{-1}\right)$. At each of the time points $(1$, 6 and $12 \mathrm{~h}$ ) following dosing, six rats were sacrificed and brain, liver and kidney tissues were collected. Tissue samples were rinsed with physiological saline to remove blood or content, weighed, blotted on filter paper, and then stored in a freezer at $-20^{\circ} \mathrm{C}$ until HPLCMS/MS analysis.

\section{HPLC-MS/MS quantitative analysis of ritonavir}

Conditions. - High performance liquid chromatography was performed using an Agilent 1200 HPLC system consisting of a G1312A binary pump, a G1379B degasser, a G1329A autosampler and a G1316A column oven (Agilent, USA). Ritonavir was separated on a Resteck Ultra C18 column $\left(150 \times 2.1 \mathrm{~mm}\right.$ i.d., $5.0 \mu \mathrm{m}$, USA) maintained at $20 \pm 0.5^{\circ} \mathrm{C}$ (ambient temperature of the laboratory). The mixed mobile phase delivered at $300 \mu \mathrm{L} \mathrm{min}^{-1}$ was $\mathrm{CH}_{3} \mathrm{CN} /$ $\mathrm{H}_{2} \mathrm{O}, 67.75: 22.25(\mathrm{~V} / \mathrm{V})$, containing $0.2 \mathrm{mmol} \mathrm{L}^{-1} \mathrm{NH}_{4} \mathrm{COOH}$ in $\mathrm{CH}_{3} \mathrm{CN}$ and $\mathrm{H}_{2} \mathrm{O}$. The retention times of ritonavir and the internal standard in plasma samples were approximately 2.5 and $3.3 \mathrm{~min}$, respectively. Detection was carried out on an API Qtrap 5500 MS/MS system (Applied Biosystems, USA) equipped with an electrospray interface (ESI) and operated in the positive ionization mode. Multiple-reaction monitoring (MRM) at unit resolution was employed to monitor the transitions of molecular ions ([M-H]) of ritonavir at $m / z 721.4 \rightarrow 296.2$ and that of the internal standard at $m / z 671.4 \rightarrow 570.4$. Optimized MS parameters were: curtain gas, gas 1 (nitrogen), and gas 2 (nitrogen) 206.85, 275.8 and $275.8 \mathrm{kPa}$, respectively, dwell time $200 \mathrm{~ms}$, ionspray voltage $+4500 \mathrm{~V}$, ion source temperature $500^{\circ} \mathrm{C}$, declustering potential (DP) $0 \mathrm{~V}$ for ritonavir, and $0 \mathrm{~V}$ for the internal standard; collision energy (CE) $-26 \mathrm{~V}$ for ritonavir and $-46 \mathrm{~V}$ for the internal standard (volt is a standard unit of parameters in the instrument). Data acquisition and analysis were performed using the analyst software version 1.5.1 (Applied Biosystems, Foster City, CA, USA). 
Ritonavir in HBMECs. - The intracellular concentration of ritonavir in HBMECs was determined by HPLC-MS/MS. No effect on cell viability was observed at these concentrations during the incubation period (data not shown). Results were normalized to the protein content of cells in each well $(22,23)$. The protein content in the lysate solution of cells was determined using the commercially available BCA protein assay. The accumulation of ritonavir was expressed as uptake per mg protein of the cells relative to the drug concentration (ng kg-1 protein).

Ritonavir in blood plasma. - Ritonavir in plasma was determined after the following treatment. Prior to the determination, $200 \mu \mathrm{L}$ of IS (saquinavir) working solution $\left(20 \mathrm{ng} \mathrm{mL}^{-1}\right)$, $500 \mu \mathrm{L}$ of sodium tetraborate $\left(0.1 \mathrm{mmol} \mathrm{L}^{-1}\right)$ and $3 \mathrm{~mL}$ methyl tert-butyl ether were added to a $10-\mu \mathrm{L}$ aliquot of plasma in a 7-mL Eppendorf tube. The mixture was vortex-mixed for $10 \mathrm{~min}$ and centrifuged at $4000 \mathrm{rpm}$ for $5 \mathrm{~min}$. The upper layer $(2.8 \mathrm{~mL})$ was carefully transferred to another 7-mL clean Eppendorf tube and evaporated at $40{ }^{\circ} \mathrm{C}$ under a gentle stream of nitrogen. The dry residue was then reconstituted with the $400 \mu \mathrm{L}$ of mobile phase and vortex-mixed for $3 \mathrm{~min}$. Finally, a $10 \mu \mathrm{L}$ of the solution was injected into the HPLC-MS/MS system.

Ritonavir in tissues. - For determination of ritonavir in a tissue, each weighed tissue sample was thawed and then homogenized in ice-cold physiological saline $(1: 10, m / V)$. The tissue homogenate was then taken and processed further like plasma samples. Finally, $10 \mu \mathrm{L}$ of each sample solution was analyzed by HPLC-MS/MS system.

\section{Pharmacokinetics}

The pharmacokinetic parameters of ritonavir were analyzed by non-compartmental analysis using the PK-Solver Program (version 2.0, China Medicinal University, Nanjing, China). The elimination rate constant $\left(K_{\mathrm{el}}\right)$ was calculated by log-linear regression of ritonavir concentration data during the elimination phase, and the terminal half-life $\left(t_{1 / 2}\right)$ was calculated as $0.693 / K_{\mathrm{el}}$. The peak concentration $\left(c_{\max }\right)$ of ritonavir in plasma as well as the time to reach $c_{\max }\left(t_{\max }\right)$, were obtained by visual inspection of the data from the concentration-time curve. The area under the plasma concentration-time curve (AUC) from time zero to the time of the last measured concentration $\left(c_{\text {last }}\right)$ was calculated by means of the linear trapezoidal rule. $A U C_{0-\infty}$ was determined by adding $A U C_{0-t}$, and the extrapolated area was determined by calculating $c_{\text {last }} / K_{\mathrm{el}}$. Mean residence time $(M R T)$ was the estimated time for $63.2 \%$ of the administered dose to be eliminated. The total body clearance of oral $(\mathrm{Cl} / \mathrm{F}$, here $\mathrm{F}$ represents the bioavailability of ritonavir) ritonavir was calculated from the quotient of the dose and the $A U C_{0-\infty}$.

\section{Data analysis}

All analyses were performed using SPSS (SPSS 11.0, SPSS, Inc., Chicago, USA). For comparisons of the mean values between two experimental groups, Student's unpaired $t$-test was used. Comparisons between three or more experimental groups were performed using a one-way analysis of variance, followed by Dunnett's test. Differences were considered statistically significant when $p<0.05$. 


\section{RESULTS AND DISCUSSION}

\section{HPLC-MS/MS validation}

The method was checked according to the guidelines for bioanalytical method validation. The calibration curve for ritonavir was linear over the concentration range $0.1-100 \mathrm{ng} \mathrm{mL}^{-1}$, which were found to be adequate for the analysis of the lysate solution of cells, plasma and tissues. The quantitation limit, with a coefficient of variation of less than $20 \%$, was $0.1 \mathrm{ng}$ $\mathrm{mL}^{-1}$. Inter- and intra-day coefficients of variation for the low, middle, and high quality control samples were less than $15 \%$. Ritonavir was found stable when kept at $25^{\circ} \mathrm{C}$ for $24 \mathrm{~h}$, at $-20{ }^{\circ} \mathrm{C}$ for 30 days, and after 3 freeze-thaw cycles.

\section{Effect of flavonoids on intracellular accumulation of ritonavir in HBMECs}

In the accumulation assay, the intracellular level of ritonavir in HBMECs was measured after $4 \mathrm{~h}$ of incubation with various flavonoids (Fig. 1). The positive control verapamil at $100 \mu \mathrm{mol} \mathrm{L} \mathrm{L}^{-1}$ significantly increased $(p<0.01)$ the intracellular accumulation of ritonavir by $133.2 \%$ compared to the control (ritonavir alone). Among the eight flavonoids, hesperetin, quercetin, isoquercetin and EC demonstrated significant effects on the accumulation of ritonavir in HBMECs, with quercetin showing the strongest effect, with an increase of $76.9 \%$. In other words, the results indicated that quercetin had the highest potential for inhibiting P-gp, the important efflux transporter in the cell membrane.

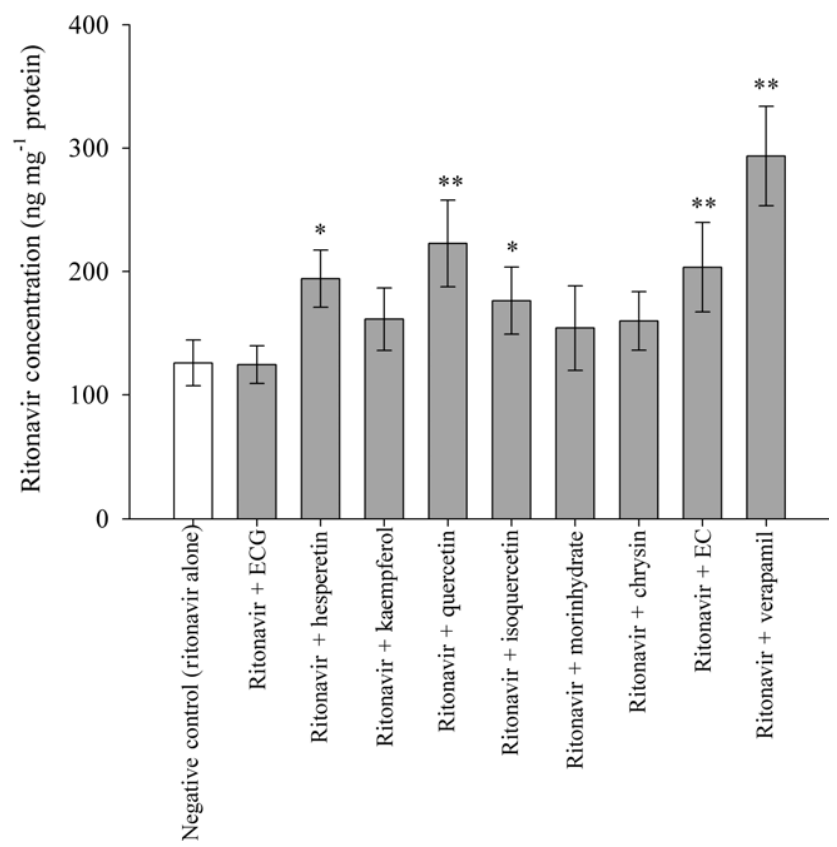

Fig. 1. Effects of $25 \mu \mathrm{mol} \mathrm{L}{ }^{-1}$ flavonoids and $100 \mu \mathrm{mol} \mathrm{L}^{-1}$ verapamil on the accumulation of ritonavir in HBMECs. Data are represented as mean \pm SD $(n=3) .{ }^{*} p<0.05$, and ${ }^{* *} p<0.01$ compared to the control. 


\section{Effect of quercetin on pharmacokinetics of orally administered ritonavir}

The mean arterial plasma concentration-time profiles of ritonavir following oral administration in the presence or absence of quercetin are illustrated in Fig. 2 and the pharmacokinetic parameters of ritonavir are summarized in Table I. Compared to the control group (ritonavir alone), the presence of quercetin in the co-administration group and the pretreatment group significantly decreased $A U C_{0-\mathrm{t}}$ of ritonavir by $42.2 \%(p<0.05)$ and $53.5 \%$ $(p<0.01)$, and markedly decreased the peak plasma concentration $\left(c_{\max }\right)$ of ritonavir by $23.1 \%$ $(p<0.05)$ and $45.8 \%(p<0.01)$, respectively. The time to reach maximum plasma concentration $\left(t_{\max }\right)$ was postponed and the $\mathrm{Cl} / \mathrm{F}$ of ritonavir was increased in the presence of quercetin. In addition, no significant changes in $t_{1 / 2}$ and $M R T$ of ritonavir were found after quercetin co-administration either the co-administration group or the pretreatment group.

\section{Effect of quercetin on tissue distribution of orally administered ritonavir}

The tissue distribution results of orally administered ritonavir in the absence or presence of quercetin are shown in Table II. The ritonavir concentration in the brain was markedly increased $(p<0.01)$, by $205.3 \%$, during the absorption phase $(1 \mathrm{~h})$, and was still significantly higher $(p<0.05)$ than the control during the distribution phase $(6 \mathrm{~h})$ when

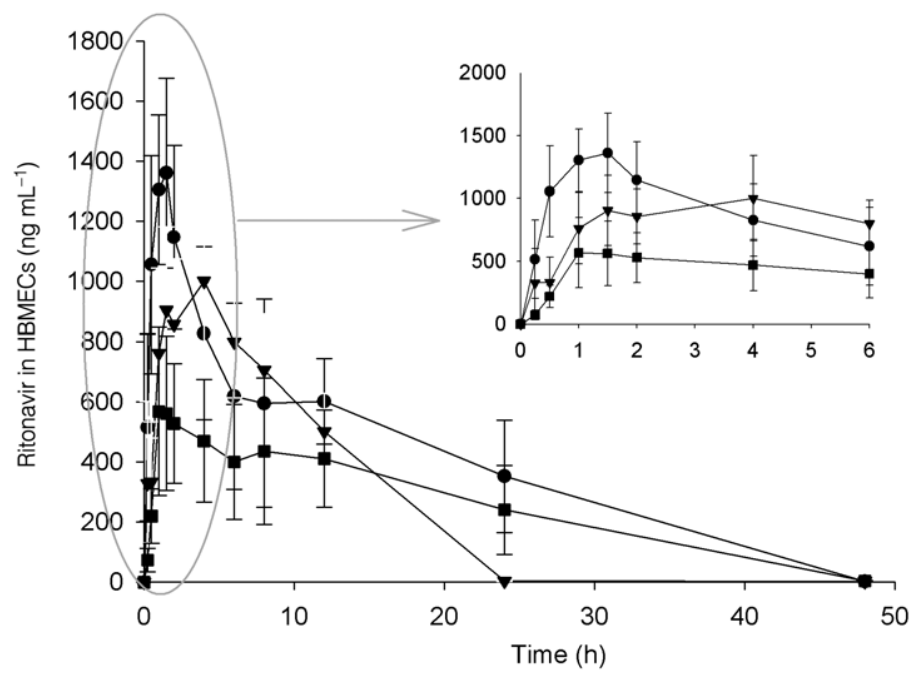

Fig. 2. Mean plasma concentration-time profiles of ritonavir in rats. $(\bullet)$ Mean plasma concentration-time profiles of ritonavir in the control group rats, which were orally administered ritonavir $\left(20 \mathrm{mg} \mathrm{kg}^{-1} \mathrm{bm}\right)$ after being administered orally blank solvent for 7 consecutive days; $(\boldsymbol{\nabla})$ mean plasma concentrationtime profiles of ritonavir in the co-administration group, which were orally co-administered ritonavir $\left(20 \mathrm{mg} \mathrm{kg}^{-1} \mathrm{bm}\right)$ with quercetin $\left(100 \mathrm{mg} \mathrm{kg}^{-1} \mathrm{bm}\right)$, after being orally administered blank solvent for 7 consecutive days; ( - mean plasma concentration-time profiles of ritonavir in the pretreatment group rats which were orally co-administered ritonavir $\left(20 \mathrm{mg} \mathrm{kg}^{-1} \mathrm{bm}\right)$ with quercetin $\left(100 \mathrm{mg} \mathrm{kg}^{-1} \mathrm{bm}\right)$ after being orally pretreated with quercetin $\left(100 \mathrm{mg} \mathrm{kg}^{-1} \mathrm{bm}\right)$ for 7 consecutive days. Data are represented as mean $\pm \operatorname{SD}(n=6)$. Insert: enlarged portion of up to 6 hours. 
G. Liang et al.: Effect of quercetin on the transport of ritonavir to the central nervous system in vitro and in vivo, Acta Pharm. 66 (2016) 97-107.

Table I. Pharmacokinetic parameters of ritonavir after its oral administration ${ }^{a}$ in the absence (control) or presence of quercetin ${ }^{b}$

\begin{tabular}{lccc}
\hline & \multicolumn{3}{c}{ Treatment } \\
\cline { 2 - 4 } Parameter & Ritonavir alone & $\begin{array}{c}\text { Ritonavir+quercetin } \\
(\text { once })\end{array}$ & $\begin{array}{c}\text { Ritonavir+quercetin } \\
(1 \text { week })\end{array}$ \\
\hline AUC $\left._{0-\mathrm{t}}(\mathrm{ng} \mathrm{h} \mathrm{mL})^{-1}\right)$ & $20072.74 \pm 8268.43$ & $11593.15 \pm 3567.15^{\mathrm{c}}$ & $9329.95 \pm 3668.79^{\mathrm{d}}$ \\
$c_{\max }\left(\mathrm{ng} \mathrm{mL} \mathrm{mL}^{-1}\right)$ & $1490.00 \pm 281.50$ & $1145.67 \pm 222.37^{\mathrm{c}}$ & $807.60 \pm 221.79^{\mathrm{d}}$ \\
$t_{\max }(\mathrm{h})$ & $1.20 \pm 0.27$ & $3.83 \pm 1.96^{\mathrm{d}}$ & $2.60 \pm 1.13^{\mathrm{c}}$ \\
$t_{1 / 2}(\mathrm{~h})$ & $3.54 \pm 1.14$ & $2.88 \pm 1.47$ & $4.90 \pm 2.15$ \\
$\mathrm{MRT}(\mathrm{h})$ & $9.25 \pm 4.29$ & $7.62 \pm 1.29$ & $9.11 \pm 2.34$ \\
$\mathrm{Cl} / \mathrm{F}\left(\mathrm{L} \mathrm{mg} \mathrm{m}^{-1}\right)$ & $0.00148 \pm 0.00070$ & $0.00187 \pm 0.00063$ & $0.00283 \pm 0.00124^{\mathrm{c}}$ \\
\hline
\end{tabular}

Data are represented as mean \pm SD $(n=6)$.

a $20 \mathrm{mg} \mathrm{kg}^{-1} \mathrm{bm}$.

b $100 \mathrm{mg} \mathrm{kg}^{-1} \mathrm{bm}$.

${ }^{c} p<0.05,{ }^{\mathrm{d}} p<0.01$ compared to the control.

$A U C_{0-\mathrm{t}}$ - area under the plasma concentration-time curve from time zero to the time of last measured concentration, $c_{\max }$ - peak concentration; $t_{\max }$ - time to reach peak concentration, $t_{1 / 2}$-terminal half-life, $M R T$, mean residence time, $\mathrm{Cl} / \mathrm{F}$ - total body clearance, $\mathrm{F}$ - bioavailability.

Table II. Distribution of ritonavir in the brain, liver and kidney after its oral administration in the absence (control) or presence of quercetin

\begin{tabular}{|c|c|c|c|c|c|c|}
\hline \multirow{2}{*}{ 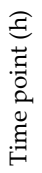 } & \multicolumn{2}{|c|}{ Brain $\left(\right.$ ng g $\left.^{-1}\right)$} & \multicolumn{2}{|c|}{ Liver $\left(\right.$ ng g $\left.^{-1}\right)$} & \multicolumn{2}{|c|}{ Kidney $\left(\right.$ ng g $\left.^{-1}\right)$} \\
\hline & $\begin{array}{l}\text { Ritonavir } \\
\text { alone }\end{array}$ & $\begin{array}{l}\text { Ritonavir + } \\
\text { quercetin }\end{array}$ & Ritonavir alone & $\begin{array}{c}\text { Ritonavir + } \\
\text { quercetin }\end{array}$ & Ritonavir alone & $\begin{array}{c}\text { Ritonavir + } \\
\text { quercetin }\end{array}$ \\
\hline 1 & $135.34 \pm 46.40$ & $413.23 \pm 190.90^{\mathrm{b}}$ & $97166.61 \pm 12084.66$ & $90346.67 \pm 15751.75$ & $16976.67 \pm 5680.02$ & $19580.00 \pm 5040.83$ \\
\hline 6 & $95.33 \pm 24.41$ & $129.87 \pm 28.74^{\mathrm{a}}$ & $40773.33 \pm 12362.32$ & $70253.33 \pm 16920.70^{b}$ & $15979.32 \pm 6853.40$ & $12809.87 \pm 5521.29$ \\
\hline 12 & $56.43 \pm 21.35$ & $54.41 \pm 16.20$ & $36102.09 \pm 16824.33$ & $34980.00 \pm 12815.24$ & $14080.00 \pm 1442.64$ & $8107.09 \pm 2826.15^{\mathrm{b}}$ \\
\hline
\end{tabular}

Data are represented as mean $\pm \mathrm{SD}(n=6)$. Ritonavir dose $20 \mathrm{mg} \mathrm{kg}^{-1}$; quercetin dose $100 \mathrm{mg} \mathrm{kg}^{-1}$. ${ }^{\mathrm{a}} p<0.05$, and ${ }^{\mathrm{b}} p<0.01$ compared to the control.

co-administrated with quercetin. There were no significant changes for ritonavir concentration in the brain in the elimination phase $(12 \mathrm{~h})$, with or without quercetin. Ritonavir concentration in the liver was significantly increased $(p<0.01)$, by $72.3 \%$, during the distribution phase $(6 \mathrm{~h})$, and showed no significant change in the absorption phase $(1 \mathrm{~h})$ or 
elimination phase either (12 h). However, the ritonavir concentration in the kidney tissue decreased markedly $(p<0.01)$, by $42.4 \%$, during the elimination phase $(12 \mathrm{~h})$ but had no significant changes either during the absorption $(1 \mathrm{~h})$ or distribution phase $(6 \mathrm{~h})$.

It can be seen that there was a wide changing range of SD within the parameters in Table II. One reason is that all the analyses were based on the data of 6 experimental animals in each group, which could be considered as a small sample size. Other reasons are still to be explored. K. Berginc et al. (24) investigated the impact of garlic flavonoids on the hepatic pharmacokinetics of saquinavir and darunavir. It was very confusing that aged garlic extract significantly inhibited saquinavir efflux from rat hepatocytes, while the efflux of darunavir significantly increased. The authors inferred that the competition between saquinavir and garlic constituent(s) for the same binding site on the efflux transporter and the positive cooperative effect between darunavir and garlic phytochemical(s), which bind to separate binding places on the transporter, are the most probable mechanisms. In our study, ritonavir was used as the test drug, whose chemical structure is different from saquinavir and darunavir, so the exact mechanism is still unclear. We must admit that the current manuscript is just a primary exploratory study and our group will consistently investigate the detailed mechanism in the future.

\section{Summary of the study}

In this study, we assessed the effects of eight flavonoids on the accumulation of ritonavir in HBMECs and found that quercetin was the most effective in improving the intracellular concentration of ritonavir. Further, the in vivo experiment sought to determine if quercetin could serve as an agent to improve the brain concentration of ritonavir in rats. Based on the results of animal experiments, we found that quercetin had a significant effect on the pharmacokinetics of ritonavir in rats. After co-administration with quercetin, the postponed $t_{\max }$ in rats demonstrated that the absorption of ritonavir was slowed down. The $A U C_{0-\mathrm{t}}$ and $c_{\max }$ were decreased, which indicated that the amount of ritonavir exposed in plasma was reduced. However, the concentration of ritonavir in the brain increased significantly when orally co-administrated with quercetin. The results of tissue studies were consistent with the results of the intracellular accumulation assay of ritonavir in HBMECs. Many reports indicate that flavonoids modulate the cell multi-drug resistance mediated by P-gp (25-27), which plays a role in the barrier function of BBB. As ritonavir is a substrate of P-gp, modulating P-gp might be a mechanism that could improve the concentration of ritonavir in the brain. Quercetin, which has a consistent effect on the modulation of ritonavir in vitro and in vivo, might become a safe and effective agent for increasing HPIs levels within the brain.

\section{CONCLUSIONS}

This study found that quercetin screened from the in vitro experiment had a significant effect on the pharmacokinetics of ritonavir in rats and could markedly enhance the distribution of ritonavir into the brain in vivo. These findings suggest a new strategy that might result in higher brain distributions reduced toxicity, and improved efficacy of HPIs by using a plant-derived flavonoid as a chemosensitizer.

Acknowledgements. - This paper was supported by a Grant of the National Natural Science Foundation of China (No. 81102877). 
G. Liang et al.: Effect of quercetin on the transport of ritonavir to the central nervous system in vitro and in vivo, Acta Pharm. 66 (2016) 97-107.

\section{REFERENCES}

1. S. A. Thomas, Anti-HIV drug distribution to the central nervous system, Curr. Pharm. Des. 10 (2004) 1313-1324; DOI: 10.2174/1381612043384835.

2. J. A. Zastre, G. N. Chan, P. T. Ronaldson, M. Ramaswamy, P. O. Couraud, I. A. Romero, B. Weksler, M. Bendayan and R. Bendayan, Up-regulation of P-glycoprotein by HIV protease inhibitors in a human brain microvessel endothelial cell line, J. Neurosci. Res. 87 (2009) 1023-1036; DOI: 10.1002/ jnr.21898.

3. M. Ahn, S. Ghaemmaghami, Y. Huang, P. W. Phuan, B. C. May, K. Giles, S. J. DeArmond and S. B. Prusiner, Pharmacokinetics of quinacrine efflux from mouse brain via the P-glycoprotein efflux transporter, PLoS One 7 (2012) e39112; DOI: 10.1371/journal.pone.0039112.

4. D. Pal, D. Kwatra, M. Minocha, D. K. Paturi, B. Budda and A. K. Mitra, Efflux transporters- and cytochrome P-450-mediated interactions between drugs of abuse and antiretrovirals, Life Sci. 88 (2011) 959-971; DOI: 10.1016/j.lfs.2010.09.012.

5. A. Antinori, G. Arendt, J. T. Becker, B. J. Brew, D. A. Byrd, M. Cherner, D. B. Clifford, P. Cinque, L. G. Epstein, K. Goodkin, M. Gisslen, I. Grant, R. K. Heaton, J. Joseph, K. Marder, C. M. Marra, J. C. McArthur, M. Nunn, R. W. Price, L. Pulliam, K. R. Robertson, N. Sacktor, V. Valcour and V. E. Wojna, Updated research nosology for HIV-associated neurocognitive disorders, Neurology 69 (2007) 1789-1799; DOI: 10.1212/01.WNL.0000287431.88658.8b.

6. L. Varatharajan and S. A. Thomas, The transport of anti-HIV drugs across blood-CNS interfaces: summary of current knowledge and recommendations for further research, Antiviral Res. 82 (2009) A99-A109; DOI: 10.1016/j.antiviral.2008.12.013.

7. J. W. Polli, J. L. Jarrett, S. D. Studenberg, J. E. Humphreys, S. W. Dennis, K. R. Brouwer and J. L. Woolley, Role of P-glycoprotein on the CNS disposition of amprenavir (141W94), an HIV protease inhibitor, Pharm. Res. 16 (1999) 1206-1212; DOI: 10.1023/A:1018941328702.

8. E. F. Choo, B. Leake, C. Wandel, H. Imamura, A. J. Wood, G. R. Wilkinson and R. B. Kim, Pharmacological inhibition of P-glycoprotein transport enhances the distribution of HIV-1 protease inhibitors into brain and testes, Drug Metab. Dispos. 28 (2000) 655-60.

9. S. Park and P. J. Sinko, P-glycoprotein and mutlidrug resistance-associated proteins limit the brain uptake of saquinavir in mice, J. Pharmacol. Exp. Ther. 312 (2005) 1249-1256; DOI:10.1124/ jpet.104.076216.

10. C. J. Bachmeier, T. J. Spitzenberger, W. F. Elmquist and D. W. Miller, Quantitative assessment of HIV-1 protease inhibitor interactions with drug efflux transporters in the blood-brain barrier, Pharm. Res. 22 (2005) 1259-1268; DOI: 10.1007/s11095-005-5271-y.

11. M. Hamidi, Role of P-glycoprotein in tissue uptake of indinavir in rat, Life Sci. 79 (2006) 991-998; DOI: 10.1016/j.lfs.2006.05.010.

12. U. Roy, C. Bulot, K. Höner zu Bentrup and D. Mondal, Specific increase in MDR1 mediated drugefflux in human brain endothelial cells following co-exposure to HIV-1 and saquinavir, PLoS One 8 (2013) e75374; DOI: 10.1371/journal.pone.0075374.

13. Z. Binkhathlan and A. Lavasanifar, P-glycoprotein inhibition as a therapeutic approach for overcoming multidrug resistance in cancer: current status and future perspectives, Curr. Cancer Drug Targets 13 (2013) 326-346; DOI: 10.2174/15680096113139990076.

14. A. Palmeira, E. Sousa, M. H. Vasconcelos and M. M. Pinto, Three decades of P-gp inhibitors: skimming through several generations and scaffolds, Curr. Med. Chem. 19 (2012) 1946-2025; DOI: 10.2174/092986712800167392.

15. H. A. Namanja, D. Emmert, D. A. Davis, C. Campos, D. S. Miller, C. A. Hrycyna and J. Chmielewski, Toward eradicating HIV reservoirs in the brain: inhibiting P-glycoprotein at the blood-brain barrier with prodrug abacavir dimers, J. Am. Chem. Soc. 134 (2012) 2976-2980; DOI: 10.1021/ ja206867t. 
16. M. T. Sheu, Y. B. Liou, Y. H. Kao, Y. K. Lin and H. O. Ho, A quantitative structure-activity relationship for the modulation effects of flavonoids on p-glycoprotein-mediated transport, Chem. Pharm. Bull. (Tokyo) 58 (2010) 1187-1194; DOI: 10.1248/cpb.58.1187.

17. P. Limtrakul, O. Khantamat and K. Pintha, Inhibition of P-glycoprotein function and expression by kaempferol and quercetin, J. Chemother. 17 (2005) 86-95; DOI: 10.1179/joc.2005.17.1.86.

18. D. Pal and A. K. Mitra, MDR- and CYP3A4-mediated drug-herbal interactions, Life Sci. 78 (2006) 2131-2145; DOI: 10.1016/j.lfs.2005.12.010.

19. J. Patel, B. Buddha, S. Dey, D. Pal and A. K. Mitra, In vitro interaction of the HIV protease inhibitor ritonavir with herbal constituents: changes in P-gp and CYP3A4 activity, Am. J. Ther. 11 (2004) 262-277.

20. S. Zhou, X. Feng, P. Kestell, J. W. Paxton, B. C. Baguley and E. Chan, Transport of the investigational anti-cancer drug 5,6-dimethylxanthenone-4-acetic acid and its acyl glucuronide by human intestinal Caco-2 cells, Eur. J. Pharm. Sci. 24 (2005) 513-524; DOI: 10.1016/j.ejps.2005.01.006.

21. X.Y. Yu, S. G. Lin, Z. W. Zhou, X. Chen, J. Liang, X. Q. Yu, B. Chowbay, J. Y. Wen, W. Duan, E. Chan, X.T. Li, J. Cao, C. G. Li, C. C. Xue and S. F. Zhou, Role of P-glycoprotein in limiting the brain penetration of glabridin, an active isoflavan from the root of Glycyrrhiza glabra, Pharm. Res. 24 (2007) 1668-1690; DOI: 10.1007/s11095-007-9297-1.

22. Y. J. Moon and M. E. Morris, Pharmacokinetics and bioavailability of the bioflavonoid biochanin A: effects of quercetin and EGCG on biochanin A disposition in rats, Mol. Pharm. 4 (2007) 865-872; DOI: $10.1021 / \mathrm{mp} 7000928$.

23. J. G. Sarver, W. A. Klis, J. P. Byers and P. W. Erhardt, Microplate screening of the differential effects of test agents on Hoechst 33342, rhodamine 123, and rhodamine 6G accumulation in breast cancer cellsthatoverexpress P-glycoprotein, J. Biomol.Screen 7(2002)29-34;DOI:10.1177/108705710200700105.

24. K. Berginc, I. Milisav and A. Kristl, Garlic flavonoids and organosulfur compounds: Impact on the hepatic pharmacokinetics of saquinavir and darunavir, Drug Metab. Pharmacokin. 25 (2010) 521-530; DOI: JST.JSTAGE/dmpk/DMPK-10-RG-053 [pii].

25. A. Di Pietro, G. Conseil, J. M. Pérez-Victoria, G. Dayan, H. Baubichon-Cortay, D. Trompier, E. Steinfels, J. M. Jault, H. de Wet, M. Maitrejean, G. Comte, A. Boumendjel, A. M. Mariotte, C. Dumontet, D. B. McIntosh, A. Goffeau, S. Castanys, F. Gamarro and D. Barron, Modulation by flavonoids of cell multidrug resistance mediated by P-glycoprotein and related ABC transporters, Cell. Mol. Life Sci. 59 (2002) 307-322; DOI: 10.1007/s00018-002-8424-8.

26. J. B. Vaidyanathan and T. Walle, Cellular uptake and efflux of the tea flavonoid (-)epicatechin-3gallate in the human intestinal cell line Caco-2, J. Pharmacol. Exp. Ther. 307 (2003) 745-752; DOI: 10.1124/jpet.103.054296.

27. Y. Li, J. L. Revalde, G. Reid and J. W. Paxton, Interactions of dietary phytochemicals with ABC transporters: possible implications for drug disposition and multidrug resistance in cancer, Drug Metab. Rev. 42 (2010) 590-611; DOI: 10.3109/03602531003758690. 